\title{
Pigmented uveal tumours in a transgenic mouse model
}

Theresa R Kramer, Marianne B Powell, Matthew M Wilson, Jennifer Salvatore, Hans E Grossniklaus
Conclusion-Pigmented intraocular tumours developed in transgenic strains of mice that express a mutated Ha-ras gene in melanin producing cells. The morphology was most consistent with a melanoma in two of the mice and a benign melanocytic/RPE proliferation in the remaining mice.

(Br f Ophthalmol 1998;82:953-960) served phenotypically.

Methods-Transgenic TPras mice $(n=8)$ and normal, age matched control mice $(n=6)$ were sacrificed at 3 weeks, 6 weeks, 7 weeks, 4 months, 5 months, 9 months, and 11 months. Six were processed in formalin for light microscopic examination and eight in a glutaraldehyde/formalin solution for electron microscopic examination.

Results-Six of the TPras mice were found to have bilateral pigmented melanocytic/RPE proliferations of the uveal tract. The cytological characteristics of the tumours included low nuclear to cytoplasmic ratios (N:C ratios), bland nuclei, and abundant intracytoplasmic melanin. By EM two populations of cells were identified, including spindle-shaped cells with round to oval melanin granules and cuboidal cells with apically located, cigar-shaped, melanin granules, and basement membrane formation. A 3 week and an 11 month old TPras mouse had a higher grade, bilateral, melanocytic proliferation of the uveal tract which, although not metastatic, was morphologically melanoma. Cytological features included increased $\mathrm{N}$ : $\mathrm{C}$ ratios, nuclear pleomorphism, and prominent nucleoli. The uveal tract was normal in both eyes in all of the control animals.
Choroidal melanoma is a primary intraocular cancer and is the most common ocular cancer among adults. Ocular cancers account for approximately $1 \%$ of all new cancers cases in the United States each year. ${ }^{1}$ Other less common intraocular cancers in adults include melanoma of the iris and ciliary body. Although rare, this condition is of special concern within the field of ophthalmology because of its life threatening potential.

Primary ocular melanoma can arise from the choroid, ciliary body, iris, conjunctiva, or less commonly from the orbital structures, lacrimal system, cornea, and retina. It is the most common primary malignancy of the eye in adults. ${ }^{2}$ There are several animal models of intraocular melanoma which have proved useful in studying tumour development and therapeutic modalities. ${ }^{3}$ In addition, several research groups have been successful in developing experimental mouse $\mathrm{e}^{4-6}$ or transgenic mouse lines ${ }^{7-11}$ for the study of intraocular pigmented tumours and melanoma. The latter authors used a tyrosinase promoter to regulate expressequences in melanocytes. The mice they generate develop pigmented ocular tumours at a young age. We have developed transgenic mouse strains at the Arizona Cancer Center using a tyrosinase promoter to target sion of the SV40 early region transforming

Sciences Center,

Tucson, Arizona, USA

M B Powell

J Salvatore

Department of

Ophthalmology,

Emory Eye University,

Atlanta, Georgia, USA

M M Wilson

H E Grossniklaus

Correspondence to: Theresa

R Kramer, MD,

Departments of

Ophthalmology and

Pathology, University of

Arizona, $1801 \mathrm{~N}$ Campbell

Avenue Tucson, AZ 85719 ,

USA.

Accepted for publication

29 January 1998

Table 1 Summary of the pathological findings in the TPras mice and the control mice

Pathological findings in mice eyes

\begin{tabular}{|c|c|c|c|c|c|}
\hline Number & Age & Type & Ocular pathology & Neuropathology & $E M$ \\
\hline 1 & 3 weeks & ras & $\begin{array}{l}\text { iris/ciliary body moderately pigmented } \\
\text { melanoma }\end{array}$ & normal & no \\
\hline 2 & 6 weeks & ras & melanocytic/RPE hamartoma & benign melanocytic proliferation & yes \\
\hline 3 & 7 weeks & ras & melanocytic/RPE hamartoma & 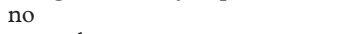 & yes \\
\hline 4 & 5 months & ras & melanocytic/RPE hamartoma & normal & yes \\
\hline 5 & 4 months & ras & melanocytic/RPE hamartoma & no & yes \\
\hline 6 & 9 months & ras & melanocytic/RPE hamartoma & benign melanocytic proliferation & no \\
\hline 7 & 11 months & ras & melanocytic/RPE hamartoma & normal & no \\
\hline 8 & 11 months & ras & $\begin{array}{l}\text { iris/ciliary body moderately pigmented } \\
\text { melanoma }\end{array}$ & no & yes \\
\hline 9 & 3 weeks & normal & normal & normal & no \\
\hline 10 & 5 weeks & normal & RPE proliferation & normal & yes \\
\hline 11 & 3 months & normal & normal & normal & yes \\
\hline 12 & 9 months & normal & normal & normal & no \\
\hline 13 & 9 months & normal & normal & no & yes \\
\hline 14 & 11 months & normal & normal & no & no \\
\hline
\end{tabular}


expression of the mutated T24 Ha-ras gene in melanin producing cells. ${ }^{10}$ Two independent founder mice were found to have a distinct phenotype with muted agouti coat colour, deeply pigmented skin with multiple naevi and "twirling behaviour". Histopathology of the tissue revealed hyperpigmentation and/or melanocytic hyperplasia in the skin, eyes, inner ear, and meningeal membranes in the brain. Histopathology and electron microscopy (EM) were performed to characterise the intraocular tumours observed phenotypically. In this paper, we report the histopathological characterisation of the ocular tumours.

\section{Methods}

TPRAS TRANSGENIC MICE

An expression vector using mouse tyrosinase promoter sequences to drive expression of the mutated human Ha-ras (T24) gene was used to generate the TPras transgenic mice. The pTPras construct contains a 2.5 kilobase $(\mathrm{kb})$ tyrosinase promoter fragment isolated from the plasmid GL3. ${ }^{12}$ The promoter fragment was
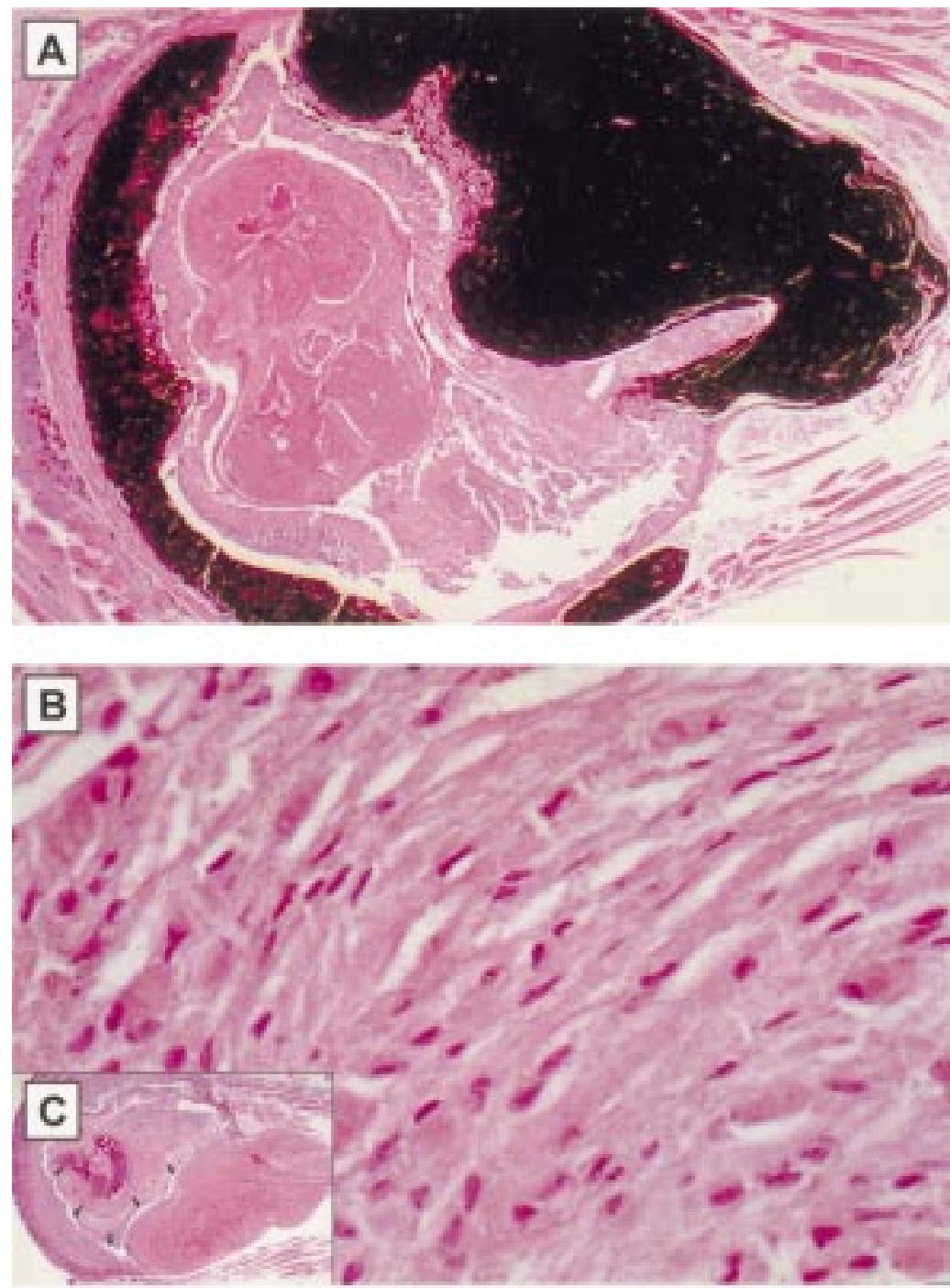

Figure 1 (A) Light micrograph of melanocytic hamartoma in the uveal tract of TPras transgenic mice. The melanocytic proliferation is seen to fill the entire uveal tract. Cells are deeply pigmented and morphological features are not readily discernible (haematoxylin and eosin, original magnification $\times 10$ ). (B) High power light micrograph of the bleached specimen demonstrates the cytological characteristics of the melanocytic/RPE hamartoma with oval nuclei with bland nuclear characteristics (haematoxylin and eosin, original magnification $\times 10$ ). Inset $(C)$ : Bleached specimen demonstrates a proliferation of plump polyhedral to spindle-shaped cells diffusely filling the uveal tract. ligated into $\mathrm{pR} 8-\mathrm{T} 24$, a promoterless construct which contains the genomic sequences of the mutant T24 c-Ha-ras gene ${ }^{13}$ in the pIC-20R vector. A $6.5 \mathrm{~kb}$ fragment isolated from the pTPras plasmid was used for microinjection to generate the transgenic mice. The exact procedure used to generate the transgenic mice has been completely described by Powell and colleagues. $^{10}$

The mice used for this study are on C57BL/ 6XSJL X C3He/N background. Expression of the T24 Ha-ras mRNA is detected in tissues containing melanocytes such as skin, eyes, and meningeal membrane. The mice exhibit a distinct phenotype consisting of a muted agouti coat colour, pigmented skin, and twirling behaviour. ${ }^{10}$ Mice were randomly chosen to represent a range of ages and sacrificed for pathological evaluation. All animals were treated in accordance with the ARVO resolution on animals used in research.

LIGHT AND ELECTRON MICROSCOPIC STUDIES Whole mice heads were fixed in $10 \%$ buffered formalin. Specimens were then dehydrated in a series of alcohols and embedded in paraffin. Serial sections 4-6 $\mu \mathrm{m}$ thick were subsequently stained with haematoxylin and eosin for routine light microscopic evaluation. Selected samples were also fixed in $2.5 \%$ glutaraldehyde/0.1 molar cacodylate buffer solution, postfixed in osmium tetroxide, and subsequently embedded in LX 112 resin (Ladd Res Ind Inc, USA) for transmission electron microscopy. For transmission electron microscopy, semithin sections $(1-2 \mu \mathrm{m})$ were stained with toluidine blue and sodium borate (1\%) and examined by light microscopy. Ultrathin sections $(60-70 \mathrm{~nm})$ were stained with aqueous uranyl acetate followed by lead citrate and examined using a Jeol 100CX electron microscope.

\section{Results}

Bilateral intraocular tumours arose in the TPras mice. The tumours were identified histopathologically and ultrastructurally as melanoma and mixed melanocytic/retinal pigment epithelial (RPE) hamartomas. In addition, a benign melanocytic proliferation of the choroid plexus was identified in two of the TPras mice. In this report, we examine the ocular tissues from TPras transgenic mice at several different ages and compare them with age matched negative littermates. Table 1 summarises the histopathological and ultrastructural findings in the TPras mice $(n=8)$ and the control mice $(n=6)$. The ocular tissue examined from one of the normal control littermates contained an RPE proliferation.

Six of the TPras mice were found to have pigmented hamartomatous proliferations of the uveal tract. These were composed primarily of proliferations of heavily pigmented, spindle-shaped melanocytes with low nuclear to cytoplasmic ratios, bland nuclei, and abundant intracytoplasmic melanin pigment (Fig 1). Occasionally, more atypical cytological characteristics were observed in these pigmented hamartomatous proliferations. These 


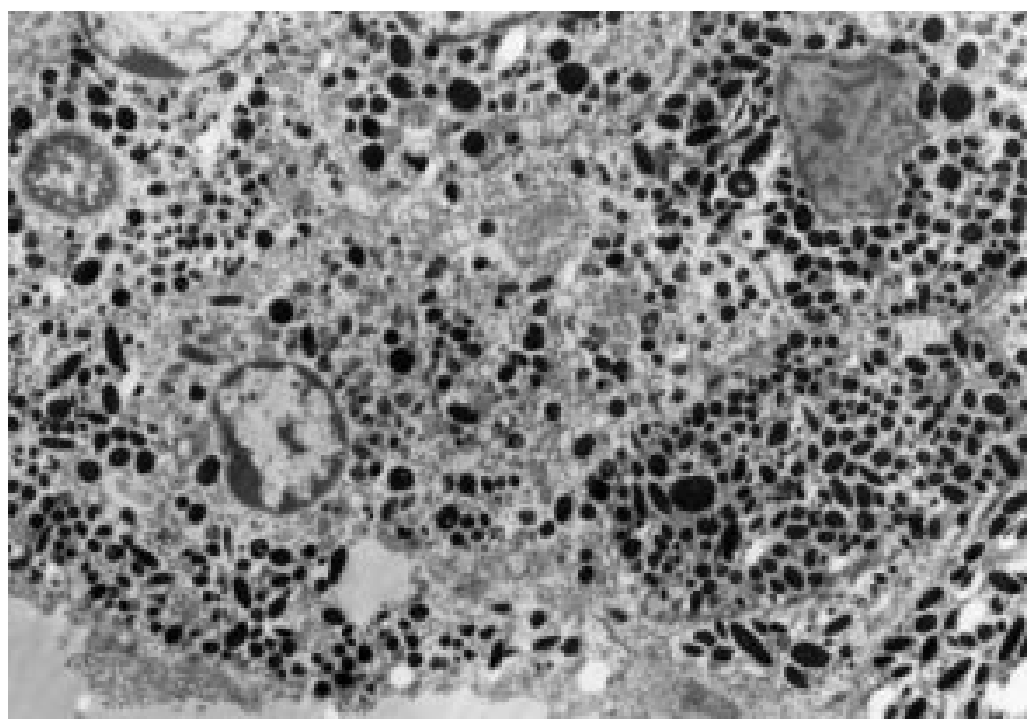

Figure 2 An electron micrograph of a melanocytic hamartoma in the uveal tract of TPras transgenic mice. Both spindle cells and cuboidal cells with oval nuclei containing marginated heterochromatin are identified. Intracytoplasmic membranous vesicles, premelanosomes, phagosomes, and cigar-shaped and oval melanin granules are identified. The melanosomes measure between 0.4 and $1.50 \mu \mathrm{m}$. Atypical nuclear features are identified in one cell (lower left) which contains a prominent nucleolus (original magnification $\times 5510$ ).
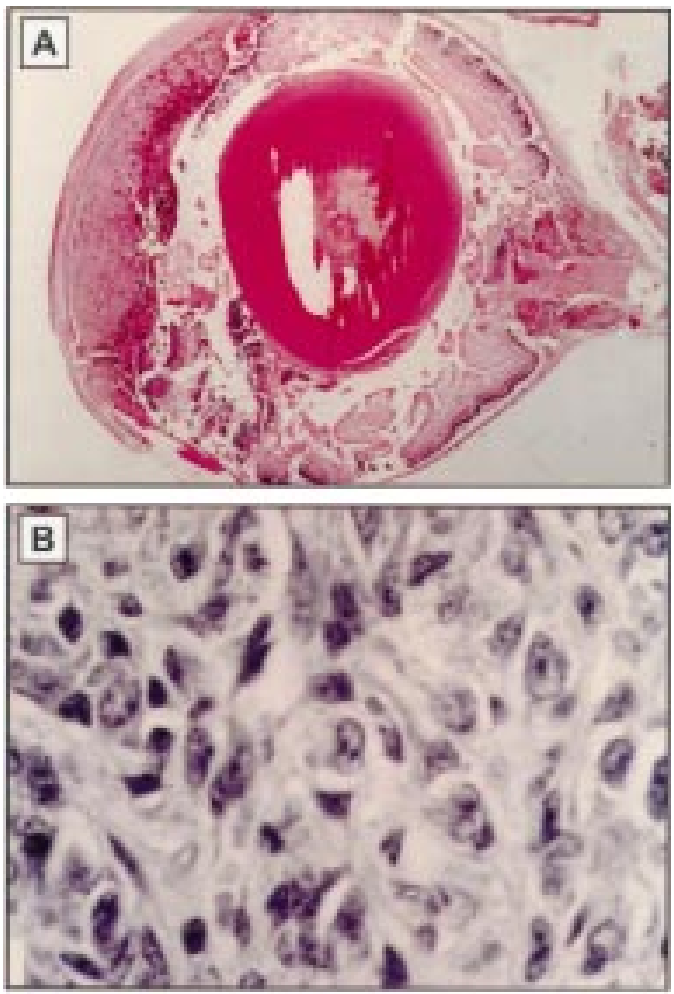

tumours massively filled the entire uveal tract. Four of the six tumours were examined by electron microscopy in addition to histopathological examination. The majority of the cells identified had ultrastructural characteristics which included spindle-shaped cells with oval to round nuclei and numerous intracytoplasmic oval melanosomes and premelanosomes (Fig 2). This cell type did not display intercellular junctions or basement membrane formation. Less frequently, cells which had cuboidal shape with rounded nuclei, apical to basal polarity, and intracytoplasmic cigar-shaped melanin granules were identified. These cells displayed intercellular junctions and basement membrane formation.

The remaining two TPras mice, a 3 week and an 11 month mouse had a higher grade melanocytic proliferation which was morphologically melanoma. The tumours were present in the iris, ciliary body, and the anterior chamber and were characterised histopathologically as a proliferation of moderately pigmented uveal melanocytes (Fig 3). Cytological features included increased nuclear to cytoplasmic ratios, nuclear pleomorphism, and prominent nucleoli. Ultrastructurally, the cells were spindle shaped with oval to round nuclei, increased nuclear to cytoplasmic ratios, marginated chromatin, irregular nuclear envelope, and prominent nucleoli. Intracytoplasmic melanin granules were demonstrated. The round to oval melanosomes measured $0.53 \mu \mathrm{m}$ by 0.87 $\mu \mathrm{m}$ (range $0.41-0.75 \mu \mathrm{m}$ and $0.75-1.08 \mu \mathrm{m}$ ) (Fig 3). The uveal melanocytic tumour in the 11 month TPras mouse also contained melanophages and areas of retinal pigment epithelial proliferation. None of the mice were shown to have metastatic tumours.

Two of the six TPras mice were also noted to have benign melanocytic proliferations in the brain. These were characterised histopathologically as small proliferations of moderately

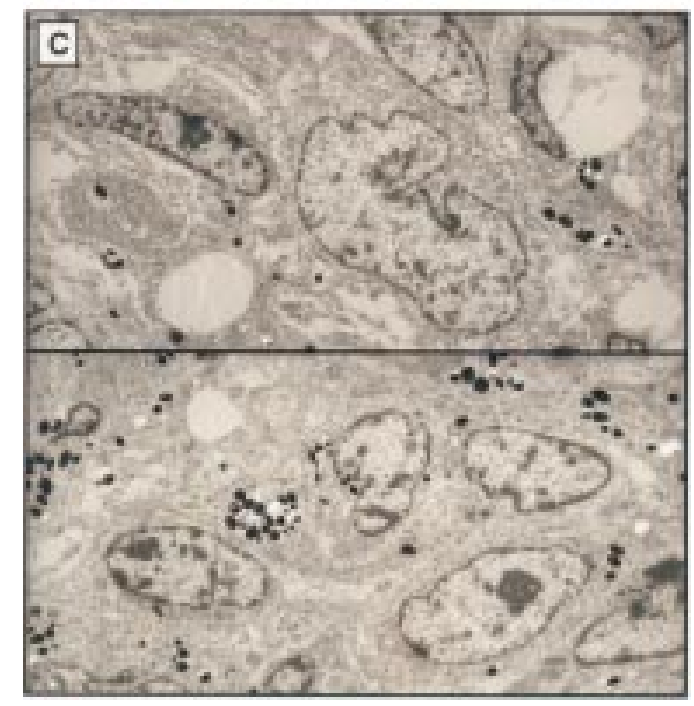

Figure 3 (A) Light micrograph of melanoma in the uveal tract of TPras transgenic mice. The melanocytic proliferation is seen to fill the entire uveal tract. Cells are moderately pigmented and morphological features are not readily discernible (haematoxylin and eosin, original the bleached specimen demonstrates a proliferation of pleomorphic, spindle-shaped cells. The cytological characteristics of the malignant melanoma in the 3 week TPras mouse are demonstrated. (C) Ultrastructurally, the cells are spindle shaped with oval to round nuclei, increased nuclear to cytoplasmic ratios, marginated chromatin, irregular nuclear envelope, and prominent nucleoli. Intracytoplasmic melanin granules are demonstrated (haematoxylin and eosin, original magnification $\times 160$ ).

to heavily pigmented melanocytes in the choroid plexus. These melanocytes were entirely bland and morphologically characterised as plump polyhedral cells similar to naevus cells. Ultrastructural examination was not done because of the benign morphology on histopathological examination.

The uveal tract was normal in all six of the control animals (negative littermates). magnification $\times 10$ ). (B) High power light micrograph of 

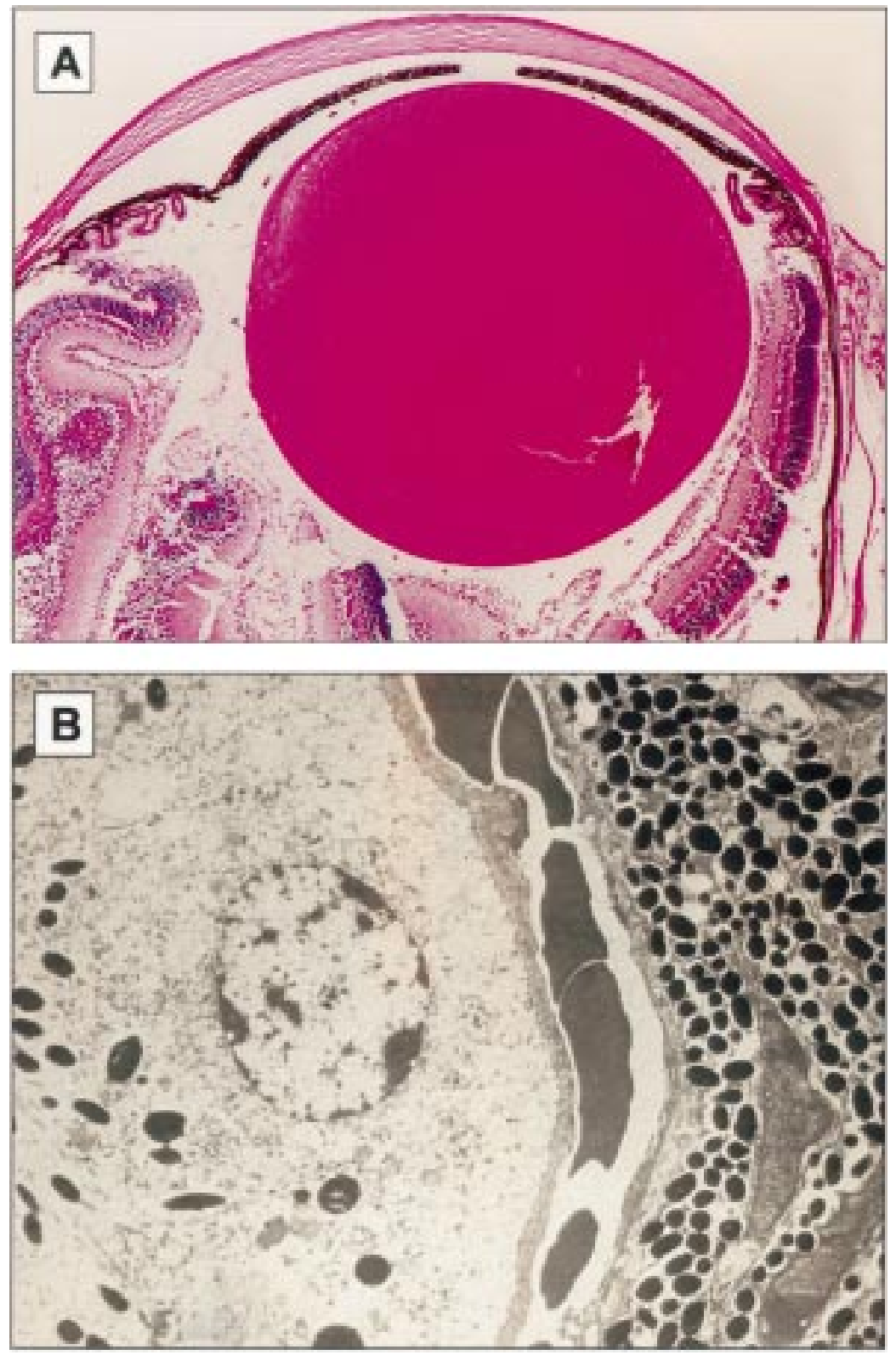

Figure 4 (A) Photomicrograph of the anterior uveal tract in one of the control (negative littermate) mice. The iris ciliary body and choroid are pigmented and normal in structure. There is no evidence of infiltration hyperplasia or hypertrophy of the uveal tract (original magnification $\times 44$ ). (B) Electron micrograph demonstrating the retinal/choroidal junction in one of the control mice. Choroidal melanocytes are spindle-shaped cells with oval nuclei containing a bland chromatin pattern. Intracytoplasmic round and oval melanin granules are identified. The melanosomes measure $0.50 \mu \mathrm{m}$ by $0.75 \mu \mathrm{m}$. The RPE is composed of cuboidal cells with oval nuclei containing marginated heterochromatin. There is apical to basal polarity and basement membrane formation. Intracytoplasmic rough endoplasmic phagosomes and membranous vesicles are identified. Intracytoplasmic cigar-shaped and oval melanin granules are identified and measure $0.44 \mu \mathrm{m}$ by $1.58 \mu \mathrm{m}$ (original magnification $\times 9180$ ).
Intracytoplasmic rough endoplasmic phagosomes and membranous vesicles were identified.

An RPE proliferation, confirmed by electron microscopy, was discovered in one control mouse ( 5 weeks). This was characterised, histopathologically, as a melanotic proliferation of RPE cells between the retina and choroid. The cells were noted to form tubuloacinar configurations. Ultrastructural characteristics included apical to basal polarity, abundant basement membrane proliferation, and intercellular junctional complexes (Fig 5).

\section{Discussion}

In order to better understand the pathobiology of uveal malignant melanoma, numerous investigators have developed models of ocular melanoma. These models have been reviewed extensively and the potential limitations and advantages of each model have been discussed by Albert et al. ${ }^{14}$ These have included heterotransplantation models, ${ }^{15-18}$ models induced by a DNA oncogenic virus (papova, C-type, retrovirus), and chemically induced models. ${ }^{19-22}$ In addition, models with transplantation of melanoma cells into the anterior chamber and the posterior compartment of the eye have been established. ${ }^{5}{ }^{6}$ In the model of Grossniklaus, ${ }^{6}$ mice were inoculated in the anterior chamber or posterior compartment with B16F10 melanoma cells. Melanoma was demonstrated in both compartments and these melanomas metastasised to the lungs. Newer models of ocular melanoma have included transgenic mouse models. These models are based on using the promoter region of the tyrosinase gene to target expression of oncogenes to pigment producing cells of different origins. Most of the models have been successful in producing intraocular pigmented tumours including RPE tumours, carcinomas, and ocular melanosis. ${ }^{7-11}$ These models are summarised in Table 2.

Powell et al, in an attempt to develop an animal with cutaneous melanoma, reported hyperpigmentation and melanocytic hyperplasia in transgenic mice expressing the human T24 Ha-ras gene regulated by a mouse tyrosinase promoter. ${ }^{10}$ The mutated Ha-ras was used to generate the transgenic mice based on observations of the occurrence of ras mutations in human cutaneous melanoma. ${ }^{23}$ Phenotypically, these transgenic mice displayed a muted agouti coat, highly pigmented skin, and a twirling movement. Although no cutaneous melanoma developed, primarily benign melanocytic lesions were observed in the skin and tissues of the inner ear and uveal tract. ${ }^{10}$ In our study, we determined that the cellular composition of the spontaneously arising pigmented ocular tumours that developed in the TPras transgenic mice expressing a mutated Ha-ras gene represented a proliferation of melanocytes intermixed with RPE cells. The cytological characteristics of the tumour cells included a spindle/dendritic shape with abundant intracytoplasmic melanosomes and premelanosomes. These cells had round to oval melanin granules. A second population of cells were cuboidal with cigar-shaped RPE was composed of cuboidal cells with oval nuclei containing marginated heterochromatin. There was apical to basal polarity and basement membrane formation. 

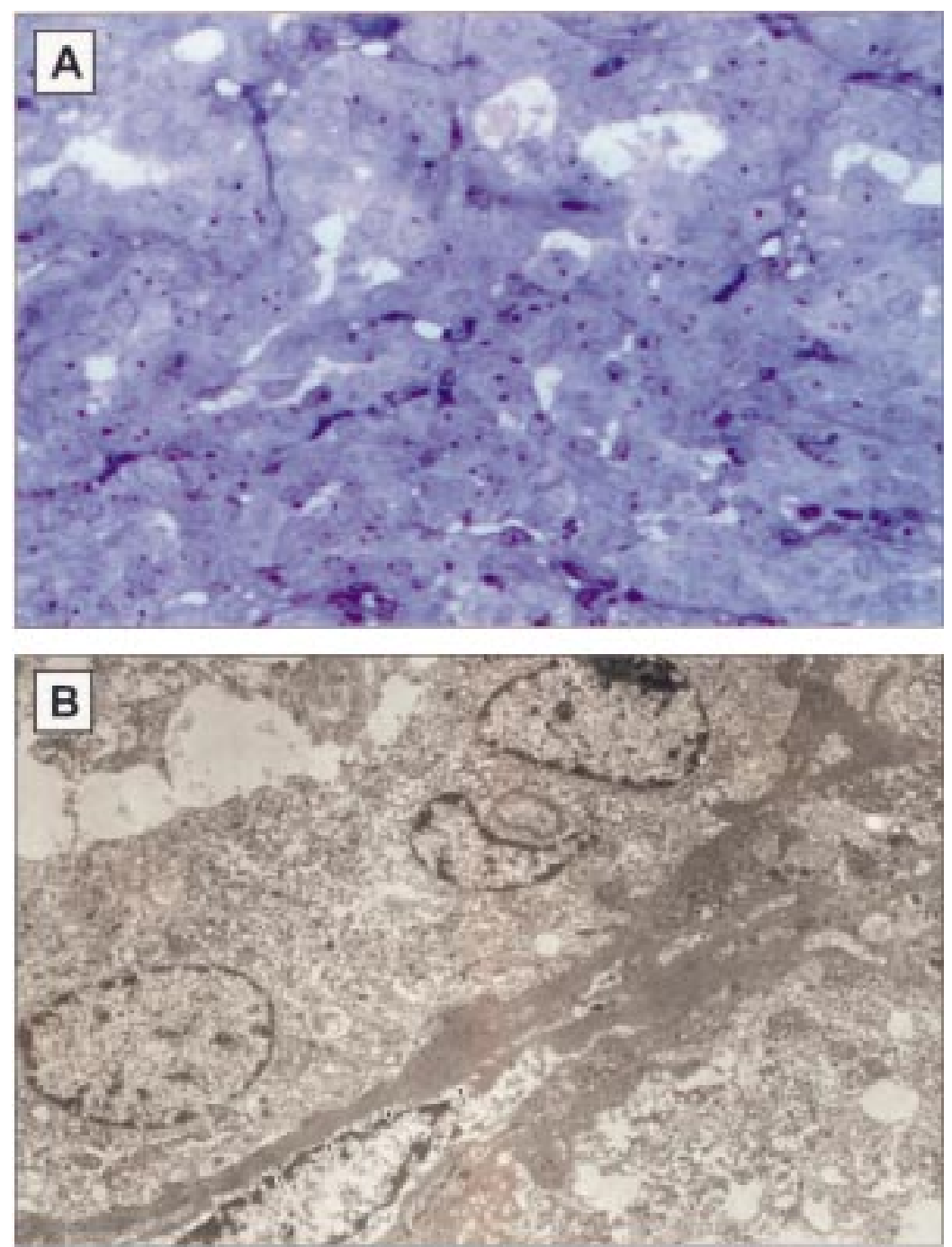

Figure 5 (A) Light micrograph demonstrating a retinal pigment epithelial adenomatous proliferation found in the uveal tract of a normal control litter mate. (B) Histopathologically, this was characterised as a melanotic proliferation of RPE between the retina and the choroid. The cells were noted to form tubuloacinar configurations (haematoxylin and eosin, original magnification $\times 160$ ).

melanin granules characteristic of RPE cells. Some of the cells had intercellular junctions and basement membrane formation characteristic of pigment epithelial cells such as iris pigment epithelium, RPE, and ciliary pigment epithelium. These cells also displayed apical to basal polarity and abundant basement membrane formation typical of epithelial cells. Thus, we have concluded that the majority of the cellular proliferations in the uveal tract of the transgenic mice represented a combined melanocytic/RPE proliferation.

The identification of cell type in the uveal tumours of the TPras mice was based on morphological and ultrastructural characteristics of the intraocular pigmented cells in the human eye. In this respect, several types of pigment containing cells are generally recognised within the eye, including iris pigment epithelium, pigmented ciliary epithelium, retinal pigment epithelium, and uveal melanocytes. Pigmented epithelial cells and melanocytes of the eye have different morphological characteristics, are known to arise embryologically from different tissue origins, and behave in biologically distinct ways.

Uveal melanocytes are generally recognised as dendritic cells with a spindle shape and an elongated, oval nucleus containing peripherally marginated chromatin. Numerous oval melanosomes are present in the cytoplasm and many of the melanosomes contain a striated substructure. ${ }^{24}{ }^{25}$ Intracytoplasmic melanin granules in uveal melanocytes measure 0.6-0.8 $\mu \mathrm{m}$ in diameter. ${ }^{26}$ Melanocytes residing in skin, iris, and choroid are neural crest derivatives. Uveal melanocytes do not begin to produce pigment until late in embryological development and continue to produce pigment after birth. ${ }^{24}$ Intraocular pigmented epithelial cells are morphologically epithelial rather than dendritic. The RPE cells contain larger ellipsoidal to needle-shaped pigment granules. ${ }^{24}{ }^{27}$ Intracytoplasmic melanin granules in the RPE are cigar shaped and measure $1 \mu \mathrm{m}$ in diameter and $2-3 \mu \mathrm{m}$ in length. ${ }^{27} \mathrm{RPE}$ cells arise from the outer layer of the optic cup. Melanin granules are found in the RPE at about the 10th week of gestation. ${ }^{27}$ Between the eighth and 14 th week of gestation, granules of all stages can be found including premelanosomes and melanosomes. ${ }^{28}$ The RPE density also increases from birth to age 2 years. ${ }^{29}$ In the mouse, the first pigment in the retinal region appears around day $11-11.5$ of gestation. ${ }^{30} 31$

Uveal malignant melanoma is a cellular proliferation of cytologically malignant melanocytes. The cytological characteristics of uveal malignant melanoma were originally described by Callendar, ${ }^{32}$ who recognised two main cell types, spindle and epithelioid. Spindle-type cells of uveal malignant melanoma are fusiform and usually arranged in tightly cohesive bundles. These spindle-type cells have been divided into subtypes $A$ and $B$. Spindle A cells have a small, slender nucleus with a fine, delicate, chromatin structure, and ill defined or absent nucleoli. Often a nuclear fold passing along the length of the nucleus giving the appearance of a nuclear streak. Mitotic figures are rarely seen. Spindle B cells have a larger, plumper nucleus containing a coarse chromatin network and a small round, sharply defined, eosinophilic nucleolus. $\mathrm{Mi}$ totic figures are often observed. Callendar's

Table 2 Transgenic model of ocular tumours

\begin{tabular}{|c|c|c|c|c|c|}
\hline \multirow[b]{2}{*}{ Investigator } & \multirow[b]{2}{*}{ Model name } & \multirow[b]{2}{*}{ Target gene } & \multirow[b]{2}{*}{$R P E$} & \multicolumn{2}{|l|}{ Predominant cell type } \\
\hline & & & & Melanocytes & Metastases \\
\hline Bradl, Klein-Szanto, 1991 & Tyr-SV40E & SV40 & $\mathrm{RPE}$ proliferations & Not reported & Numerous organs \\
\hline Anand, 1994 & SV40 & SV40 & RPE proliferations & Not reported & Liver \\
\hline Syed, 1995,1996 & Tyr-Tag A, Tyr-Tag B & SV40 & $\begin{array}{l}\text { RPE, spindle, and epithelioid } \\
\text { cells }\end{array}$ & Not reported & $\begin{array}{l}\text { Muscle and spleen in } \\
\text { Tag A mice }\end{array}$ \\
\hline Powell, 1995 & Tpras & T24 Ha-ras & $\mathrm{RPE}$ & Melanocytes and melanoma & $\begin{array}{l}\text { Lung and lymph nodes } \\
\text { (induced skin) }\end{array}$ \\
\hline
\end{tabular}


epithelioid cell is a larger, polygonal cell with considerable variation in both size and shape. These cells have abundant glassy cytoplasm. The nuclei of these cells are typically larger and rounder and the nuclear envelope is more angular with irregular indentations and outpouchings. The chromatin is very coarse and marginated. A very large eosinophilic nucleolus is present in the centre of the nucleus. Mitotic figures are abundant. Gamel et al $^{33}{ }^{34}$ further defined the nuclear characteristics of the various malignant melanoma cells. The modified Callendar classification now recognises spindle cell naevus, spindle cell melanoma, mixed cell melanoma, and epithelioid cell melanoma. ${ }^{35}$

In our study, we found that the majority of the uveal tumours were composed of a benign mixed melanocytic/RPE cell population in all but two of the TPras mice. However, focal areas of cytologically atypical cells were identified in many tumours. The remaining two TPras mice (the 3 week and 11 month old) had a higher grade melanocytic proliferation which was morphologically identical to melanoma. The uveal tumour was characterised histopathologically as a proliferation of moderately pigmented uveal melanocytes with malignant cytological features including increased nuclear to cytoplasmic ratios, nuclear pleomorphism, coarse chromatin network with margination, and prominent nucleoli. Pigment production in these cells was variable. Although the pigmented uveal tumour in two of the TPras transgenic mice most closely resembled human uveal malignant melanoma, true malignancy cannot be confirmed without known evidence of metastasis. We did not demonstrate metastases of the ocular tumours; however, we have found metastases to the lung and lymph node, from DMBA induced cutaneous melanoma in these same transgenic mice (Powell, personal communication). Additionally, injection of cell lines from these cutaneous tumours into SCID mice results in melanocytic tumours that invade adjacent muscle. ${ }^{36}$ In ongoing studies, we will inject these melanocytes into the anterior chamber and posterior compartment of semisyngeneic mice and assess for metastases according to the model of Grossniklaus et $a .^{56}$

Clinically, in humans, there exists a spectrum of pigmented intraocular tumours, including those derived from melanocytes and those derived from pigment epithelial cells. In order to best characterise the melanocytic proliferations in the TPras transgenic mice, we have reviewed the histopathological and cytological characteristics of the spectrum of pigmented intraocular tumours known to occur clinically in humans. ${ }^{37-65}$ Included in those presumably arising from the neural crest melanocytes are malignant melanomas, melanosis oculi, melanocytoma, diffuse choroidal spindle cell naevus, diffuse melanocytoma, and diffuse melanocytic uveal tumours associated with systemic malignant neoplasms. ${ }^{37-5258} 65$ The benign tumours all are hamartomatous proliferations of uveal melanocytes and malignant melanoma is believed to occur because of the malignant transformation of uveal melanocytes. Tumours of the RPE are mainly a result of hypertrophy and hyperplasia which most often occur as degenerative or reactive processes. ${ }^{27}$ Primary hypertrophy of the RPE can also occur in humans and has been categorised into congenital or acquired and is manifested by several patterns, including solitary hypertrophy of the RPE, congenital hypertrophy of the RPE, acquired hypertrophy of the RPE. Hyperplasia of the RPE has also been subcategorised into localised hyperplasia of the RPE and diffuse hyperplasia of the RPE. ${ }^{27}$ Finally, benign tumours of the RPE that are known to occur in humans include adenoma of $\mathrm{RPE},{ }^{27}{ }^{62-64}$ combined hamartoma of the retina and RPE, ${ }^{59-64}$ congenital hypertrophy of the $\mathrm{RPE}$ or grouped pigmentation. ${ }^{62-64}$ Rarely, primary neoplasia of the RPE, defined by specific clinical and histopathological criteria is known to occur. ${ }^{64}$

It is difficult to ascertain with certainty what the human correlate of the uveal tumours in the transgenic mice is; however, the presence of cells morphologically identifiable as melanocytes, RPE cells, and melanoma cells as well as a spectrum of cytological atypia is intriguing. Two human clinical entities seem to be the most similar. Haas and coworkers described the histopathological and ultrastructural features of a diffuse choroidal melanocytic hamartoma in a 10 year old boy. ${ }^{38}$ This tumour was composed of polygonal hyperpigmented cells and spindle-shaped cells. The cells contained well melanised melanosomes. Diffuse malignant melanoma represents $4.5 \%$ of all intraocular malignant melanomas, is more heavily pigmented, causes more RPE disturbance, grows at a faster rate, and the clinicopathological features have been reviewed by Font et al. ${ }^{65}$ Both of these human entities resemble histopathologically the tumours found in the TPras transgenic mice.

This transgenic mouse model of ocular melanocytic proliferations is distinct from other transgenic models, which have been primarily proliferations of retinal pigment epithelial cells rather than mixed RPE/melanocytic tumours. In addition, our transgenic model is the only model that consistently produces a spectrum of benign melanocytic/RPE hamartoma, morphologically atypical melanocytic/ RPE proliferations, and cytologically malignant melanoma. It is difficult to ascertain the reason for the alterations in the primary pigmented cell that is proliferating in these various transgenic models. We suspect that the expression of the SV40 gene and the Ha-ras gene during embryologic development occurs at different times, as does the production of pigment and proliferation of uveal melanocytes and RPE cells. Perhaps, expression of the different genes at different embryological stages allows for the selective or partially selective proliferation of melanocytes over RPE cells. 
In future studies, we intend to use this model to study the process of malignant transformation of uveal melanocytes to melanoma. We have already established cell culture lines of both the benign melanocytes and/or RPE cells from the melanocytic/RPE hamartomas and we intend to establish cell cultures of the melanoma cells from the malignant melanomas. As the biology of ocular melanoma and molecular mechanisms involved in malignant transformation are poorly understood, we hope to use this model along with microarray technology ${ }^{66}$ to study the molecular alterations occurring during the process of malignant transformation. Should metastases develop after injection of tumour cells into the anterior and posterior compartment, we hope to analyse the molecular alterations in metastatic tumours and compare them with primary tumours. We believe that this unique transgenic model of spontaneously arising pigmented intraocular tumours may be valuable in elucidating the pathobiological mechanisms involved in the process of malignant transformation.

Supported by NIHEY 06360, RPB, Inc; NIHCA 27502 and CA51971N, Fight for Sight Research Division to Preven Blindness America GA96100.

1 Collaborative Ocular Melanoma Study Group. Design and methods of a clinical trial for a rare condition: the Collaborative Ocular Melanoma Study, COMS Report 3. Control Clin Trials 1993;14:362-91.

2 Egan KM, Seddon JM, Glynn RJ, et al. Epidemiologic aspects of uveal melanoma. Surv Ophthalmol 1988;32:23951 .

3 Albert DM, Shadduck JA, Liu HS, et al. Animal models for the study of uveal melanoma. [Review] Int Ophthalmol Clin

4 Niederkorn JY. Suppressed cellular immunity in mice harboring intraocular melanomas. Invest Ophthalmol Vis $\mathrm{Sci}$ 1984;25:447-54.

5 Grossniklaus HE, Barron BC, Wilson MW. Murine mode of anterior and posterior ocular melanoma. Curr Eye Res 1995; 14:399-404.

6 Grossniklaus HE, Wilson MW, Barron BC, et al. Anterior vs posterior intraocular metastatic differences in a murin model. Arch Ophthalmol 1996;114:1116-20.

7 Anand $\mathrm{R}$, Ma D, Alizadeh $\mathrm{H}$, et al. Characterization of intraocular tumors arising in transgenic mice. Invest Ophthalmol Vis Sci 1994;35:3533-9.

8 Bradl M, Klein-Szanto A, Porter S, et al. Malignant melanoma in transgenic mice. Proc Natl Acad Sci USA 1991;88:164-8.

9 Klein-Szanto A, Bradl M, Porter S, et al. Melanosis and associated tumors in transgenic mice. Proc Natl Acad Sci associated tumors in

10 Powell MB, Hyman P, Bell OD, et al. Hyperpigmentation and melanocytic hyperplasia in transgenic mice expressin the human T24 Ha-ras gene regulated by a mous tyrosinase promoter. Mol Carcinog 1995;12:82-90.

11 Syed NA, Windle JJ, Darajatmoko SR, et al. Natural history of a transgenic model of intraocular melanoma. Invest $O p h-$ thalmol Vis Sci 1995;35(suppl):S1131.

12 Tanaka S, Yamamoto H, Takeuchi S, et al. Melanization in albino mice transformed by introducing cloned mouse tyrosinase gene. Development 1990;108:223 7 .

13 Bailleul B, Lang J, Wilkie N, et al. A human T24 Ha-ras cassette suitable for expression studies in eukaryotic cells. Nucleic Acids Res 1988;16:359.

14 Albert DM, Shadduck JA, Liu HS, et al. Animal models for the study of uveal melanoma. [Review] Int Ophthalmol Clin 1980;20:143-60.

15 Albert DM, Wagoner MD, Moazed K, et al. Heterotransplantation of human choroidal melanoma into the athymic "nude" mouse. Invest Ophthalmol Vis Sci 1980;19:555-9.

16 Felberg NT, Michelson JB. Pigmented iris malignan melanoma in New Zealand white rabbits. (Abstract) Ophthalmic Res 1979;11:199.

17 Gallie BL, Albert DM, Wong JJ, et al. Heterotransplantation of retinoblastoma into the athymic "nude" mouse. (Abstract) Invest Ophthalmol Vis Sci 1977;16:256.

18 Krohn DL, Brandt R, Morris DA, et al. Subchoroidal transplantation of experimental malignant melanoma. (Abstract) Am f Ophthalmol 1970;70:7531.

19 Benson WR. Intraocular tumor after ethionine and N-2 fluorenyl-acetamide. (Abstract) Arch Pathol 1962;73:404.

20 Damjanov I, Sunderman FW, Mitchell JM, et al. Induction of testicular sarcomas in Fischer rats by intratesticular injection of nickel subsulfide. (Abstract) Cancer Res 1978;38:268.
21 Furst A, Haro RT, Schlauder M. Experimental chemotherapy of nickel-induced fibrosarcomas. (Abstract) Oncology 1972;26:422.

22 Gilman JPW. Metal carcinogenesis: a study on the carcinogenic activity of cobalt, copper, iron, and nickel compounds. (Abstract) Cancer Res 1962;22:158

23 Herlyn M, Satyamoorthy K. Activated ras. Yet another player in melanoma? Am f Pathol 1996;149:739-44.

24 Zimmerman LE. Melanocytes, melanocytic nevi and melanocytomas. Invest Ophthalmol Vis Sci 1965;4:11-41.

25 Juarez CP, Tso MO. An ultrastructural study of melanocytomas (magnocellular nevi) of the optic disc and uvea. $A m$ 7 Ophthalmol 1980;90:48-62.

26 Margo CE, Grossniklaus HE. In: Zorab R, ed. Ocula histopathology: a guide to differential diagnosis. Philadelphia: Saunders, 1991.

27 Spencer WH, ed. Ophthalmic pathology: an atlas and textbook 4th ed. Philadelphia: Saunders, 1996

28 Hogan MJ, Alvarado JA, Weddell JE. Histology of the human eye: an atlas and textbook. Philadelphia: Saunders, 1971.

29 Streeten BW. Development of the human retinal pigment epithelium and the posterior segment. Arch Ophthalmol 1968;81:383-384.

30 Beerman F, Schmid E, Schutz G. Expression of the mouse tyrosinase gene during embryonic development: recapitulation of the temporal regulation in transgenic mice. Proc Nat Acad Sci USA 1992;89:2809-13.

31 Rugh R. The mouse: its reproduction and development. Oxford: Oxford University Press, 1990.

32 Callendar GR. Malignant melanotic tumors of the eye: a study of histologic types in 111 cases. Trans Am Acad Ophthalmol Otolaryngol 1931;36:131-42.

33 Gamel JW, McLean IW, Foster WD, et al. Uveal melanomas; correlation of cytologic features with prognosis. Cancer (8)

34 Gamel JW, McLean IW, Greenberg RA, et al. Computerized histologic assessment of malignant potential: a method for determining the prognosis of uveal melanomas. Hum Patho 1982;13:893-7.

35 McClean IW, Zimmerman LE, Evans RM. Reappraisal of Callendar's spindle: a type of malignant melanoma of choroid and ciliary body. Am f Ophthalmol 1978:86:55764.

36 Gause PR, Lluria-Prevatt M, Keith WN, et al. Chromosomal and genetic alterations of 7,12-dimethylbenz(a) anthracene-induced melanoma from TP-ras transgenic mice. Mol Carcinog 1997;20:78-87.

37 Barr CC, Zimmerman LE, Curtin VT, et al. Bilateral diffuse melanocytic uveal tumors associated with systemic malignant neoplasms. Arch Ophthalmol 1982;100:249-55.

38 Haas BD, Jakobiec FA, Iwamoto T, et al. Diffuse choroidal melanocytoma in a child: a lesion extending the spectrum of melanocytic hamartomas. Ophthalmology 1986;93:1632-

39 Gonder JR, Shields JA, Albert DM. Malignant melanoma of the choroid associated with oculodermal melanocytosis. Ophthalmology 1981;88:372-6.

40 Yanoff $\mathrm{M}$, Zimmerman LE. Histogenesis of malignant melanomas of the uvea. III. The relationship of congenital melanomas of the uvea. III. The relationship of congenital melanomas. Arch Ophthalmol 1967;77:331-6.

41 Albert DM, Scheie HG. Nevus of Ota with malignant melanoma of the choroid: report of a case. Arch Ophthalmo 1963;69:774-7.

42 Coats G. Unilateral diffuse melanosis of the uvea, with small elevations on the surface of the iris. Trans Ophthalmol Soc UK 1912;32:165-71.

43 Font RL, Reynolds AM Jr, Zimmerman LE. Diffuse malignant melanoma of the iris in the nevus of Ota. Arch Ophthalmol 1967;77:513-18.

44 Frezzotti R, Guerra R, Dragoni GP, et al. Malignant melanoma of the choroid in a case of naevus of Ota. Brf Ophthalmol 1968;52:922-4.

45 Halasa A. Malignant melanoma in a case of bilateral nevus of Ota. Arch Ophthalmol 1970;84:176-8.

46 Makley TA Jr, King CM. Malignant melanoma in a case of bilateral nevus of Ota. Trans Am Acad Ophthalmol Otolaryngol 1967;71:638-41.

47 Reese AB. Melanosis oculi. A case with microscopic findings. Am f Ophthalmol 1925;8:865-70.

48 Roy PE, Schaeffer EM. Nevus of Ota and choroidal melanoma. Surv Ophthalmol 1967;12:130-4.

49 Sabates FN, Yamashita T. Congenital melanosis oculi complicated by two independent malignant melanomas of the choroid. Arch Ophthalmol 1967;77:801-3.

50 Seelenfreund MH, Freilich DB. Ocular melanocytosis and malignant melanoma. NY State f Med 1979;79:916-17.

51 Yamamoto T. Malignant melanoma of the choroid in the nevus of Ota. Ophthalmologica 1969;159:1-10.

52 Naumann G, Yanoff M, Zimmerman LE. Histogenesis of malignant melanomas of the uvea. I. Histopathologic characteristics of nevi of the choroid and ciliary body. Arch Ophthalmol 1966;76:784-96.

53 Nuss DD, Aeling JL, Clemons DE, et al. Multiple hamartoma syndrome (Cowden's disease). Arch Dermatol 978;114:743-6.

54 Brownstein $\mathrm{MH}$, Mehnegan AH, Bikowski JB. Trichilemmomas in Cowden's disease. $7 A M A$ 1977;238:26.

55 Curth HO, Hilberg AW, Machacek GF. The site and histology of the cancer associated with malignant acanthosis nigricans. Cancer 1962;15:364-82.

56 Brown J, Winkelmann RK. Acanthosis nigricans: a study of 90 cases. Medicine 1968;47:33-51. 
57 Ryll DL, Campbell RJ, Robertson N, et al. Pseudometastatic lesions of the choroid. Ocular Pathol Clinicians 1980;87 $1181-6$

58 Blodi FC, Reuling H, Sornson ET. Pseudomelanocytoma at the optic nervehead. Arch Ophthalmol 1965;73:353-5.

59 McLean EB. Hamartoma of the retinal pigment epithelium. Am f Ophthalmol 1976;82:227-31.

60 Font RL, Moura RA, Shetlar DJ, et al. Combined hamartoma of sensory retina and retinal pigment epithelium. Retina 1989;9:302-11.

61 Schachat AP, Shields JA, Fine SL, et al and The Macula Society Research Committee. Combined hamartomas of the retinal pigment epithelium. Ophthalmology 1984;91: the retinal
62 Kurz GH, Zimmerman LE. Vagaries of the retinal pigment epithelium. Int Ophthalmol Clin1962;2:441-64.

63 Garner A. Tumours of the retinal pigment epithelium. Brf Ophthalmol 1970;54:715-23.

64 Tso MOM, Albert DM. Pathological condition of the retinal pigment epithelium. Arch Ophthalmol 1972;88:2736.

65 Font RL, Spaulding AG, Zimmerman LE. Diffuse malignant melanoma of the uveal tract. A clinicopathologic report of 54 cases. Trans Am Acad Ophthalmol Otolaryngol 1968;72:877-94.

66 Schena M, Shalon D, Heller R, et al. Parallel human genome analysis: microarray-based expression monitoring of 1000 analysis: microarray-based expression monitoring 